J. Clin. Chem. Clin. Biochem.

Vol. 19, 1981, pp. 155-157

\title{
Enzymatic Determination of Lipoprotein-X, a Specific Serum Cholestasis Marker
}

\author{
By E. Talafant and J. Továrek
}

Department of Medical Chemistry and Biochemistry, and Third Medical Clinic, Faculty of Medicine, University J. E. Purkynè, Brno, Czechoslovakia

(Received June 24/November 3, 1980)

Summary: Non-esterified cholesterol was determined enzymatically with the cholesterol oxidase-peroxidase reaction using phenol and 4-aminophenazone as chromogens. This assay was done in the supernatant containing the lipoprotein-X. Other serum lipoproteins were removed by precipitation with heparin and zinc acetate followed by centrifugation. No standardization was required, the lipoprotein-X concentration being calculated with the use of the constant.

\section{Enzymatische Bestimmung des für Cholestase charakteristischen Lipoprotein-X im Serum}

Zusammenfassung: Das unveresterte Cholesterin wurde enzymatisch mit der Cholesterinoxidase-Peroxidase Reaktion unter Verwendung von Phenol und 4-Aminophenazon als Chromogene bestimmt. Der Test wurde im Überstand durchgeführt, welcher das Lipoprotein-X enthielt, nachdem andere Lipoproteine durch Fällung mit Heparin und Zinkacetat und nachfolgende Zentrifugation entfernt worden waren. Keine Standardisierung war notwendig, da die Lipoprotein-X-Konzentration mittels der Konstante berechnet wurde.

\section{Introduction}

Lipoprotein-X, a specific marker of cholestasis, was hitherto determined by rather complicated procedures. Its quantitative determination may be helpful, e.g. for differentiating between the intra- and extrahepatic cholestasis in infants receiving cholestyramine, (Campbell, D. P. \& Williams, R. G., cf. in 1.c. (1)). The turbidimetric method of Goverde et al. (2) utilizes antiserum to remove the interacting lipoproteins. The turbidimetric method without antibody described in the previous paper (3) suffers from the general disadvantages of measuring turbidity. It requires standardization with lipoprotein-X solution of a known concentration. The preparation of lipoprotein-X concentrate, although much simplified (3), includes collecting strongly lipoprotein-X positive sera as its source. These complications have been overcome by measuring non-esterified cholesterol by the specific enzymatic test (4). The non-esterified cholesterol represents one of the major lipoprotein-X constituents (224 g/kg) (Seidel, D., et al., cf. in 1. c. (1)). The lipoprotein- $X$ consists of the subfractions lipoprotein- $X_{1}$, lipoprotein- $X_{2}$ and lipoprotein- $X_{3}$, the cholesterol contents of which differ slightly (Patsch, J. $R$. et al., cf. in 1. c. (1)): This does not affect seriously the lipoprotein-X determinations based on its cholesterol content. The lipoproteins other than lipoprotein-X were removed from the examined serum using the principle devised by Soběslavský and modified in the method previously described (3).

\section{Materials and Methods}

Spekol 10 (Carl Zeiss, Jena GDR) with plastic cuvettes (Sarstedt, Nümbrecht-Rommelsdorf, FRG), light path $1 \mathrm{~cm}$, width $0.4 \mathrm{~cm}$, height $3.1 \mathrm{~cm}$ (cut from the original height of $4.5 \mathrm{~cm}$ ) were used for measurements. From the commercial kit "Cholesterin, Boehringer Mannheim CHOD-PAP Methode, No. 172626" only the solutions 1 and 2 (the chromogens) were used to prepare the reagent: 1 volume of the solution $l$ with 1 volume of the solution 2 were mixed and for each $\mathrm{ml}$ of this mixture about $8 \mu \mathrm{l}$ of cholesterol oxidase (EC 1.1.3.6) suspension ( $25 \mathrm{kU} / \mathrm{l}$, Boehringer Mannheim, No. 126934), followed by $8 \mu$ l of an aqueous solution of horse radish peroxidase (EC 1.11.1.7) (Sigma Chem. Co., Type I) $3 \mathrm{~g} / \mathrm{l}$, and $10 \mu \mathrm{l}$ of aqueous $0.12 \mathrm{~mol} / \mathrm{l}$ EDTA.

The examined serum $(150 \mu \mathrm{l})$ was diluted with $150 \mu \mathrm{l}$ of an aqueous solution containing $1 \mathrm{~g} / 1$ heparin and $0.15 \mathrm{~mol} / 1 \mathrm{NaCl}$. After mixing $30 \mu \mathrm{l}$ of aqueous $0.26 \mathrm{~mol} / \mathrm{l}$ zinc acetate solution were added, mixed well and incubated in a water bath for about $1 \mathrm{~h}$ at $40^{\circ} \mathrm{C}$. Then the tube was cooled to room teniperature $\left(23-25^{\circ} \mathrm{C}\right)$ in a water bath for $5 \mathrm{~min}$ and centrifuged at about $3000 \mathrm{~g}$ for $15 \mathrm{~min}$. To $100 \mu \mathrm{l}$ of the supernatant $500 \mu \mathrm{l}$ of the cholesterol reagent were added, incubated at $38^{\circ} \mathrm{C}$ for $15-20 \mathrm{~min}$ and the red colour was read at $500 \mathrm{~nm}$ against a blank consisting of $100 \mu \mathrm{l}$ of $0.15 \mathrm{~mol} / 1 \mathrm{NaCl}$ incubated with $500 \mu l$ of the reagent. When the colour was too deep to be measured only 50 or $25 \mu \mathrm{l}$ of the supernatant diluted with 50 or $75 \mu \mathrm{l}$ of $0.15 \mathrm{~mol} / 1 \mathrm{NaCl}$ were used and 
the results were multiplied by 2 or 4 . The resulting absorbance was multiplied by the factor 3.405 to obtain the serum lipoprotein-X concentration in $\mathrm{g} / \mathrm{l}$. This factor was derived from the data (absorbance $x$ 5.85) given in the directions (4), taking in account the real volume of serum $(45.5 \mu \mathrm{l})$ applied to the enzymatic colour reaction, the dilution factor of the reagent $\left(\frac{600}{505}\right)$, i. e. $100 \mu$ of the supernatant instead of $5 \mu$ sample

added to $500 \mu$ l of the enzymatic reagent, and the non-esterified cholesterol content of lipoprotein-X $(224 \mathrm{~g} / \mathrm{kg})$.

The removal of lipoproteins other than lipoprotein- $X$ was checked by submitting the supernatant obtained after heparin$\mathrm{Zn}^{2+}$ precipitation to agar gel electrophoresis and detection with $\mathrm{Ca}^{2+}$-dextran sulfate. No turbidity was observed on the anodic side of the well, which indicates that anodically migrating lipoproteins are virtually absent. (This check is not included into the routine procedure.) The same test was done with the lipoprotein-X concentrate (3) used for the construction of a calibration curve (fig. 1). No anodically migrating lipoproteins were detected. In this sample of lipoprotein-X concentrate the contents of phospholipids $(14.6 \mathrm{~g} / \mathrm{l})$, of non-esterified cholesterol $(5.05 \mathrm{~g} / \mathrm{l})$, and of total cholesterol $(5.75 \mathrm{~g} / \mathrm{l})$ indicated an lipoprotein-X concentration of $22 \mathrm{~g} / 1$.

\section{Results and Discussion}

Pooled sera from normal persons and the sera from various disease states were investigated by this method and the results were compared with those obtained by turbidimetry (3) and agar gel electrophoresis (table 1). The lipoprotein-X positive sera were analyzed several times (n) within one run and statistically evaluated (5). The variation coefficients (CV) were in the range of 0.61 and 4.87 , the highest $C V$ being with the lowest lipoprotein-X levels. Two samples of sera preserved with $\mathrm{NaN}_{3}(1.5 \mathrm{~g} / 1)$ were analyzed each day for 5 days and the means $(\bar{x})$ of $2.32 \mathrm{~g} / 1$ and S. D. of $0.054(\mathrm{CV}=2.33 \%)$ and $\bar{x}=5.73 \mathrm{~g} / \mathrm{l}, \mathrm{S} . \mathrm{D} .=0.102$ $(\mathrm{CV}=1.78 \%)$ were obtained. The results calculated with the use of the factor (3.405) agree well with those read from the calibration curve (fig. 1).

Unconjugated and conjugated bilirubins added to serum, although inhibitory when added directly to the supernatant, were largely removed by $\mathrm{Zn}^{2+}$ precipitation

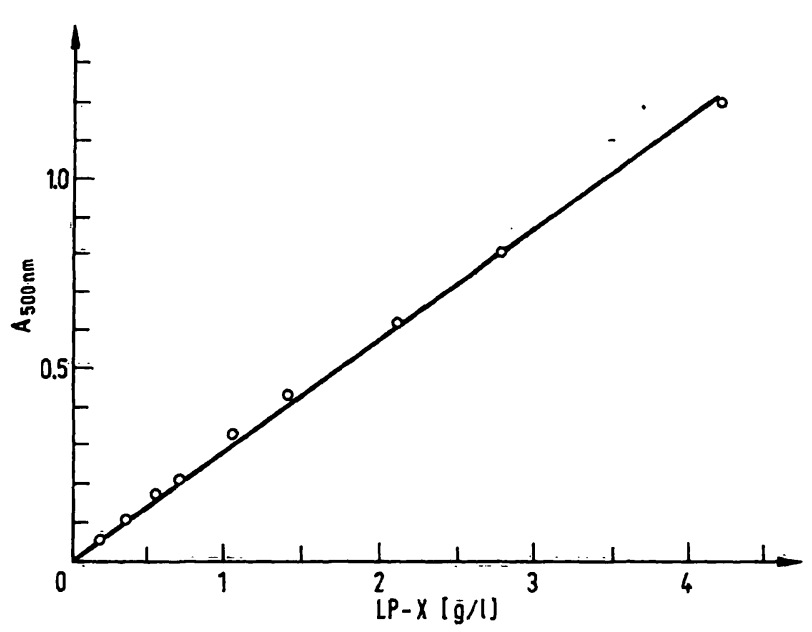

Fig. 1. Calibration curve

Absorbance values at $500 \mathrm{~nm}$. The lipoprotein-X solution of a known concentration (3) was adaed in increasing amounts to normal pooled serum to give lipoprotein-X levels indicated on the abscissa.

Tab. 1. Replicate (n) lipoprotein-X analyses by the enzymatic method, turbidimetry (3), and the agar gel electrophoretic test.

\begin{tabular}{|c|c|c|c|c|c|}
\hline \multirow[t]{2}{*}{ Diagnosis } & \multirow[t]{2}{*}{ Patient } & \multicolumn{4}{|l|}{$L P-X(g / l)$} \\
\hline & & $\begin{array}{l}\text { Enzymatic } \\
\text { (n) } \bar{x}\end{array}$ & $\bar{x} \pm$ S. D. & $\begin{array}{l}\text { Turbidi- } \\
\text { metry }\end{array}$ & $\begin{array}{l}\text { Agar electro- } \\
\text { phoresis }\end{array}$ \\
\hline $\begin{array}{l}\text { Control (pooled serum } \\
\text { of healthy persons) }\end{array}$ & - & (1) & not detectable & n. d. & $\phi$ \\
\hline Morb. hyperton. I (WHO) & R.P. $\delta$ & (1) & not detectable & n. d. & $\phi$ \\
\hline $\begin{array}{l}\text { Oblit. arter. femor., } \\
\text { hepatopathia chron. }\end{array}$ & P. R. o & (1) & not detectable & n. d. & $\phi$ \\
\hline Cholelithiasis & H. V. \& & (6) & $2.24 \pm 0.052,2.32$ & 2.30 & ++ \\
\hline $\begin{array}{l}\text { Cholangitis, chole- } \\
\text { lithiasis susp. }\end{array}$ & B. S. $\delta$ & (5) & $1.37 \pm 0.029,2.12$ & 1.45 & + \\
\hline Hepatitis chron. & S. B. ? & (4) & $1.50 \pm 0.029,1.93$ & 1.55 & + \\
\hline $\begin{array}{l}\text { Hydrops ves. felleae } \\
\text { Neoplasma pancreatis }\end{array}$ & Z. J. o & (5) & $1.26 \pm 0.032,2.54$ & 1.3 & + \\
\hline Pancreatitis acuta & H. J. 8 & (4) & $1.52 \pm 0.047,3.1$ & 1.6 & + \\
\hline $\begin{array}{l}\text { Cholecystitis chron. } \\
\text { Tumor reg. infrahepat. }\end{array}$ & J. O. $\%$ & (4) & $1.77 \pm 0.036,2.03$ & 1.85 & + \\
\hline $\begin{array}{l}\text { Cholecystitis, Pancre- } \\
\text { atitis }\end{array}$ & K. K. \& & (5) & $0.16 \pm 0.0078,4.87$ & 0.2 & \pm \\
\hline $\begin{array}{l}\text { Cholecystolithiasis, } \\
\text { Infiltr. tumorosa } \\
\text { reg. choledochi et } \\
\text { portae hepatis }\end{array}$ & $\begin{array}{l}\text { H. R. \$ } \\
\text { H. R. \& } \\
\text { serum } \\
\text { obtained } \\
10 \text { days } \\
\text { later }\end{array}$ & $\begin{array}{l}(5) \\
(4)\end{array}$ & $\begin{array}{l}5.02 \pm 0.036,0.61 \\
5.74 \pm 0.042,0.73\end{array}$ & $\begin{array}{l}5.4 \\
5.6\end{array}$ & $\begin{array}{l}+++ \\
++\end{array}$ \\
\hline
\end{tabular}


so that the inhibitory concentration in the supernatant was not attained even at a bilirubin concentration of $513 \mu \mathrm{mol} / 1$ in the serum containing $2.34 \mathrm{~g} /$ lipoprotein-X. Higher lipoprotein-X concentration caused higher bilirubin in the supernatant, while serum without lipoprotein-X yielded a supernatant with no appreciable bilirubin. Since the determination of higher lipoprotein-X levels required dilution of the supernatant, the inhibitory bilirubin concentration was never reached. Ascorbate did not inhibit when added to the analyzed serum up to a concentration of $227 \mu \mathrm{mol} / 1$. Such high serum ascorbate was not reported even after a large ascorbic acid dose (6). Sodium azide and $p$-hydroxymercuribenzoate did not inhibit in the concentrations tested (i.e. 52.4 and $3.32 \mathrm{mmol} / 1$, resp.).

The method is simple, it allows the lipoprotein- $X$ to be determined even at very low serum levels not measurable by either of the previously described methods (1) and it eliminates the need to prepare the lipopro-

\section{References}

1. Narayanan, S. (1979), CRC Critic. Revs. Clin. Lab. Sci. 11, $31-51$.

2. Goverde, B. C., Janssen, P. S. L. \& Kostner, G. M. (1978), Patent: Ger Offen. 2,806,430 (Cl. G. 01N33/16), 16 pp. (cf. Chem. Abstr. 89, 175995t).

3. Talafant, E. \& Tovärek, J. (1979), Clin. Chim. Acta 96, 261-264.
tein-X solution of a known concentration (3). The present method, like the immunoprecipitation method, is not applicable to very strongly chylous sera of milky appearance (2), e. g., a case with $12.6 \mathrm{mmol} / 1$ triglycerides and $6.92 \mathrm{mmol} / \mathrm{l}$ cholesterol gave a slight false absorbancy of 0.035 (which would correspond to $0.12 \mathrm{~g} / 1$ lipoprotein-X). This was caused by excessively increased non-lipoprotein-X lipoproteins which were not completely precipitated with heparin$\mathrm{Zn}^{2+}$.

\section{Acknowledgements}

We wish to express our thanks to Boehringer Mannheim, Biochemica GmbH (FRG) for their generous gifts of Cholesterol CHOD-PAP kits and for cholesterol oxidase. The sera of patients were kindly supplied by the staff fro $m$ the routine hospital laboratories, and the diagnoses were made available by the physicians, for which we are very grateful.
4. Boehringer Mannheim GmbH, Diagnostica (1978), Arbeitsanleitungen No. 172626.

5. Dean, R. B. \& Dixon, W. J. (1951), Anal. Chem. 23, 636-638.

6. Wells, W. W. (1974), in Clinical Biochemistry Principles and Methods (Curtius, H. C. \& Roth, M., eds.) W. de Gruyter, Berlin-New York, p. 940.
Dr. med. E. Talafant, Department of Medical Chemistry and Biochemistry, J. E. Purkyně University, Komenského nám. 2, ČS-66243 Brno, Czechoslovakia 
-

$$
\cdot
$$

